\title{
FAKTOR-FAKTOR YANG BERHUBUNGAN DENGAN HIPEREMESIS GRAVIDARUM PADA IBU HAMIL DI RB ZAKAT SURABAYA
}

\author{
Siska Nurul Abidah', Fauziyatun Nisa'2 \\ ${ }_{1,2}$ Prodi D3 Bidan, Universitas Nahdlatul Ulama Surabaya \\ Jalan SMEA No.57 Wonokromo Surabaya \\ Email: siskanurul@unusa.ac.id, fauziyatun.nisa@unusa.ac.id
}

\begin{abstract}
ABSTRAK
Mual dan muntah merupakan hal yang fisiologis terjadi dalam kehamilan muda, tetapi mual dan muntah berlanjut semakin berat akan menyebabkan hiperemesis gravidarum yang dapat menyebabkan dehidrasi dan asidoketotik. Penelitian ini bertujuan untuk menganalisis faktor- faktor yang berhubungan dengan kejadian hiperemesis gravidarum pada ibu hamil. Penelitian ini menggunakan teknik total sampling dengan pengambilan sampel dilakukan pada total populasi yang berjumlah 45 orang selama 3 bulan, populasi dan sampel adalah ibu hamil yang periksa di RB Zakat Surabaya. Pengumpulan data berupa buku register di RB Zakat Surabaya bulan JuniAgustus 2019. Menggunakan uji Chi-square. Hasil uji statistik didapatkan ada hubungan antara gravida dengan kejadian hiperemesis gravidarum $(p=0,000)$, ada hubungan antara kehamilan ganda dengan kejadian hiperemesis gravidatum $(p=0,024)$, tidak ada hubunga antara mola hidatidosa dengan kejadian hiperemesis gravidarum $(p=0,222)$, tidak ada hubungan anatara gastritis dengan kejadian hiperemesis gravidarum $(0,358)$. Diharapkan petugas kesehatan agar meningkatkan penyuluhan dan konseling bagi ibu hamil untuk mengatasi keluhan hiperemesis gravidarum.
\end{abstract}

Kata kunci: Ibu Hamil, Hiperemesis gravidarum

\section{ABSTRACT}

Nausea and vomiting are physiological things that occur in young pregnancies, but nausea and vomiting get heavier will cause hyperemesis gravidarum which can cause dehydration and acidooticosis. This study discusses to analyze the factors associated with the incidence of hyperemesis gravidarum in pregnant women. This study uses a total sampling technique that is sampling done with a total population obtained by 45 people for 3 months, the population and sample are pregnant women examined at RB Zakat Surabaya. Data collection in the form of a register at RB Zakat Surabaya in June-August 2019. Using Chi-square test. The results of the statistical test obtained there is a relationship between gravida with the incidence of hyperemesis gravidarum $(p=0,000)$, there is a relationship between multiple assessments with the incidence of hyperemesis gravidarum $(p=0.024)$, there is no relationship between hydatidiform mole with the incidence of hyperemesis gravidarum ( $p=0.222)$, whether there is a relationship between gastritis and hyperemesis gravidarum (0.358). It is hoped that health workers will increase counseling and counseling for pregnant women to overcome hyperemesis gravidarum complaints.

Keywords: Pregnant Women, Hyperemesis gravidarum 


\section{PENDAHULUAN}

Mual dan muntah merupakan hal yang umumnya terjadi dalam kehamilan dan merupakan kondisi yang fisiologis yang wajar terjadi pada kehamilan muda, yang dialami oleh 50\%-80\% wanita hamil. Mual dan muntah jika berlanjut menjadi semakin berat akan menyebabkan gangguan kehamilan yang disebut hiperemesis gravidarum yang dialami oleh 1 dalam 1000 wanita hamil, yang dapat menyebabkan dehidrasi dan asidoketotik (Price \& Wilson, 2015).

Menurut WHO pada tahun 2015 sebanyak 303.000 perempuan meninggal selama dan setelah kehamilan dan persalinan. Sekitar 830 wanita meninggal akibat komplikasi terkait kehamilan atau melahirkan diseluruh dunia setiap hari. Sebanyak 99\% kematian ibu akibat masalah persalinan atau kelahiran terjadi di negaranegara berkembang. Rasio kematian ibu per 100.000 kelahiran bayi hidup jika dibandingkan dengan rasio kematian ibu di 12 negara maju dan 51 negara persemakmuran (WHO, 2015).

Berdasarkan Survei Demografi dan Kesehatan Indonesia (SDKI), angka kematian ibu (AKI) masih cukup tinggi yaitu 359 per 100.000 kelahiran hidup. Angka kematian bayi hasil (SDKI) 2014 lebih rendah dari pada hasil 2010, angka kematian bayi tahun 2012 adalah 32 kematian per 1000 kelahiran hidup, dan salah satu penyebab kematian di Indonesia adalah bayi berat lahir rendah (SDKI,2014). Berdasarkan hasil penelitian di Indonesia diperoleh data ibu dengan hiperemesis gravidarum mencapai $14,8 \%$ dari seluruh kehamilan. Keluhan mual dan muntah terjadi pada $60-40 \%$ multigravida.

Hiperemesis gravidarum pada kehamilan muda merupakan salah satu komplikasi sebagai akibat langsung kehamilan. Meskipun bukan merupakan faktor utama penyebab kematian ibu di Indonesia, tetapi kejadian emesis cukup besar yaitu 60-80\% ada primigravida dan $40-60 \%$ pada multigravida dan satu diantara 1000 kehamilan mengalami gejala lebih berat. Oleh karena itu mual dan muntah tidak bisa dianggap ringan karena pada saat usia kehamilan muda organ-organ vital janin terbentuk dan mengakibatkan terlambatnya pertumbuhan janin yang dikandungnya sehingga zat besi tidak dapat diserap oleh janin (Hackley \& Barbara, 2012).

Pada kehamilan, selain terjadi perubahan fisiologis juga disertai perubahan psikologis. Menurut Prawirohardjo (2012) selain faktor fisiologis, psikologis memegang peranan yang tak kalah penting dalam timbulnya hiperemesis gravidarum. Perasaan mual ini disebabkan karena meningkatnya kadar hormon estrogen dan Hormon Chorionic Gonadotropin (HCG) dalam serum. Perubahan fisiologis kenaikan hormon ini belum jelas, mungkin karena sistem saraf pusat atau pengosongan lambung yang berkurang (Depkes RI, 2013).

Faktor psikis bisa memicu atau memperburuk muntah. Berat badan penderita dapat menurun dan terjadi dehidrasi, 
sehingga darah menjadi kental atau hemokonsentrasi yang dapat melambatkan peredaran darah. Hal tersebut bisa mengurangi konsumsi oksigen dan makanan ke jaringan yang bisa menimbulkan kerusakan jaringan dan menambah beratnya keadaan janin dan wanita hamil. Selain itu muntah yang berlebihan menyebabkan pecahnya pembuluh darah kapiler pada lambung sehingga muntah bercampur darah. Pembesaran bayi dalam rahim sangat tergantung terhadap asupan nutrisi ibu hamil. Muntah yang berlebihan akan membuat membuat tubuh kehilangan cairan dan hal ini akan menggangu sirkulasi darah dan metabolisme tubuh janin sehingga dapat menyebabkan bayi tumbuh kecil dalam rahim atau Intra Uterine Growth Retardation (IUGR) dan intra uterine fetal death (IUFD) (Tiran \& Denise, 2013).

Hiperemesis gravidarum umumnya sembuh dengan sendirinya (selflimiting) tetapi yang sering umum terjadi penyembuhan berjalan lambat dan berkurang. Kondisi ini paling sering terjadi diantara wanita primigravida dan cenderung terjadi lagi pada kehamilan berikutnya (Purniantika, 2011).

Bidan sebagai tenaga kesehatan mempunyai peran yang penting untuk mengatasi hiperemesis gravidarum. Berdasarkan studi pendahuluan yang dilakukan di RB Zakat didapat 15 orang ibu hamil trimester pertama 12 (80\%) orang mengalamai emesis gravidarum diantaranya mengatakan tidak tahu tentang penyebab emesis gravidarum.

Sehingga dari uraian tersebut, penulis tertarik melakukan penelitian faktor-faktor yang berhubungan dengan hiperemesis gravidarum pada ibu hamil trimester I di RB Zakat Surabaya.

\section{METODE}

Desain penelitian ini dilakukan dengan pendekatan retrospektif untuk mengatahui faktor-faktor yang mempengaruhi kejadian hiperemesis gravidarum. Populasi dan sampel yang digunakan dalam penelitian ini adalah seluruh ibu hamil yang mengalami hiperemesis gravidarum yang tercatat didalam buku register RB Zakat bulan JuniAgustus 2019 berjumlah 45 orang.

Teknik sampel menggunakan teknik total sampling yaitu dengan pengambilan sampel dilakukan pada total populasi yang berjumlah 45 orang. Peneliti mengajukan permohonan pengambilan data dari LPPM Universitas Nahdlatul Ulama Surabaya kepada Kepala RB Zakat. Setelah mendapatkan ijin pengambilan data, kemudian melakukan pendekatan dengan ibu dan menjelaskan tentang metode penelitian serta melakukan inform consent. Pengumpulan data dilakukan dengan menggunakan data sekunder berupa buku register. Buku register berisi data rekam medik dan dikelompokkan menjadi lembar isian penelitian untuk selanjutnya dilakukan analisa variabel penelitian. 
Data yang telah dikumpulkan kemudian diolah secara manual dengan menggunakan program SPSS. Hasil pengolahan data disajikan dalam bentuk tabel dan narasi. Analisa data yang digunakan adalah univariat, bivariat dengan uji statistik menggunakan Chi-Square.

\section{HASIL}

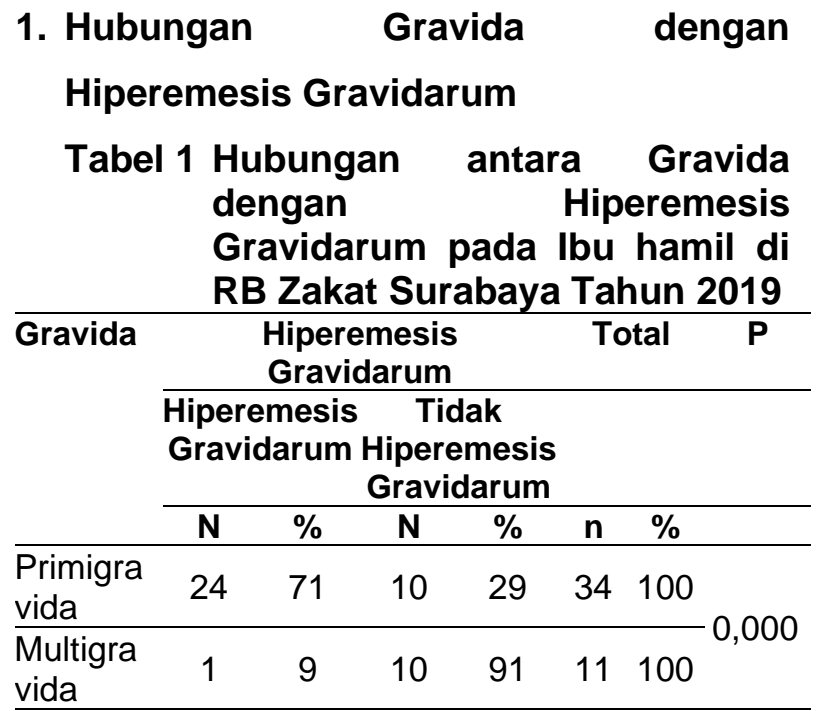

Tabel 1 menunjukkan bahwa sebagian besar (71\%) responden primigravida mengalami hiperemesis gravidarum, sedangkan sebagian besar (91 \%) responden multigravida tidak mengalami hiperemesisi gravidarum.

Hasil uji statistik diperoleh nilai $p=$ 0,000 hal ini menunjukkan bahwa $p<0,05$ yang berarti ada hubungan antara gravida dengan kejadian gravidarum.

2. Hubungan Kehamilan Ganda dengan Hiperemesis Gravidarum

Tabel 2 Hubungan antara kehamilan ganda dengan Hiperemesis
Gravidarum pada ibu hamil di RB Zakat Surabaya Tahun 2019

\begin{tabular}{|c|c|c|c|c|c|c|c|}
\hline \multirow{3}{*}{$\begin{array}{c}\text { Kehamil } \\
\text { an ganda }\end{array}$} & \multicolumn{4}{|c|}{$\begin{array}{l}\text { Hiperemesis } \\
\text { Gravidarum }\end{array}$} & \multirow{2}{*}{\multicolumn{2}{|c|}{ Total }} & \multirow[t]{3}{*}{$\mathbf{P}$} \\
\hline & \multicolumn{2}{|c|}{$\begin{array}{c}\text { Hiperemesis } \\
\text { Gravidarum }\end{array}$} & \multicolumn{2}{|c|}{$\begin{array}{c}\text { Tidak } \\
\text { Hiperemesis } \\
\text { Gravidarum }\end{array}$} & & & \\
\hline & $\mathbf{N}$ & $\%$ & $\mathbf{N}$ & $\%$ & $\mathbf{n}$ & $\%$ & \\
\hline $\mathrm{Ya}$ & 23 & 64 & 13 & 36 & 36 & 100 & \\
\hline Tidak & 2 & 22 & 7 & 78 & 9 & 100 & 0,024 \\
\hline
\end{tabular}

Berdasarkan tabel 2 didapatkan sebagian besar (64\%) responden dengan kehamilan ganda mengalami hiperemesis gravidarum, sedangkan sebagian kecil (22\%) responden dengan kehamilan tidak ganda tidak mengalamai hiperemesis gravidarum.

Hasil uji statistik diperoleh nilai $p=$ 0,024 hal ini menunjukkan bahwa $p<0,05$ yang berarti ada hubungan antara kehamilan ganda dengan kejadian hiperemesis gravidarum.

3. Hubungan Mola Hidatidosa dengan Hiperemesis Gravidarum

Tabel 3 Hubungan antara Mola Hidatidosa dengan Hiperemesis Gravidarum pada ibu hamil di RB Zakat Surabaya Tahun 2019

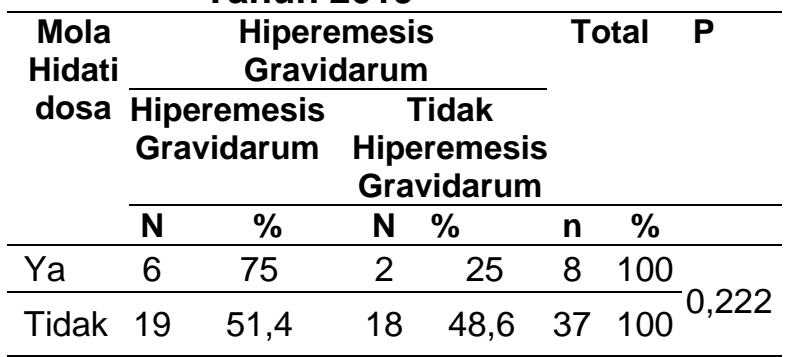

Berdasarkan tabel 3 didapatkan bahwa sebagian besar (75\%) responden dengan molahidatidosa mengalami hiperemesis gravidarum, sedangkan 
sebagian besar $(51,4 \%)$ responden yang dengan molahidatidosa mengalami hiperemesis gravidarum.

Hasil uji statistik diperoleh nilai $p=$ 0,222 hal ini menunjukkan bahwa $p>0,05$ yang berarti tidak ada hubungan antara molahidatidosa dengan kejadian hiperemesis gravidarum.

\section{Hubungan Gastritis dengan}

\section{Hiperemesis Gravidarum}

\section{Tabel 4 Hubungan antara Gastritis} dengan Hiperemesis Gravidarum pada ibu hamil di RB Zakat Surabaya Tahun 2019

\begin{tabular}{|c|c|c|c|c|c|c|c|}
\hline \multirow[t]{3}{*}{$\begin{array}{l}\text { Gastri } \\
\text { tis }\end{array}$} & \multicolumn{4}{|c|}{$\begin{array}{l}\text { Hiperemesis } \\
\text { Gravidarum }\end{array}$} & \multirow{2}{*}{\multicolumn{2}{|c|}{ Total }} & \multirow[t]{2}{*}{$\mathbf{P}$} \\
\hline & \multicolumn{2}{|c|}{$\begin{array}{l}\text { Hiperemesis } \\
\text { Gravidarum }\end{array}$} & \multicolumn{2}{|c|}{$\begin{array}{c}\text { Tidak } \\
\text { Hiperemesis } \\
\text { Gravidarum }\end{array}$} & & & \\
\hline & $\mathbf{N}$ & $\%$ & $\mathbf{N}$ & $\%$ & $\mathbf{N}$ & $\%$ & \\
\hline Iya & 18 & 47 & 20 & 53 & 38 & 100 & \\
\hline Tidak & 2 & 29 & 5 & 71 & 7 & 100 & \\
\hline
\end{tabular}

Berdasarkan tabel 4 didapatkan bahwa sebagian besar (53\%) responden dengan riwayat gastritis tidak mengalami hiperemesis gravidarum sedangkan sebagian besar (78\%) responden tidak dengan riwayat gastritis tidak mengalami hiperemesis gravidarum.

Hasil uji statistik diperoleh nilai $p=$ 0,358 hal ini menunjukkan bahwa $p>0,05$ yang berarti tidak ada hubungan antara gastritis dengan kejadian hiperemesis gravidarumHasil uji statistik diperoleh nilai $p=0,000$ hal ini menunjukkan bahwa $p<$ 0,05 yang berarti ada hubungan antara gravida dengan kejadian hiperemesis gravidarum.

\section{PEMBAHASAN}

1. Hubungan antara gravida dengan kejadian hiperemesis gravidarum pada ibu hamil

Berdasarkan tabel 1 didapatkan bahwa sebagian besar (71\%) responden primigravida mengalami hiperemesis gravidarum, sedangkan sebagian besar (91 \%) responden multigravida tidak mengalami hiperemesisi gravidarum. Hasil uji statistik diperoleh nilai $p=0,000$ hal ini menunjukkan bahwa $p<0,05$ yang berarti ada hubungan antara gravida dengan kejadian hiperemesis gravidarum.

Hal ini disebabkan karena pada primigravida belum ada kesiapan secara fisik untuk menerima pertumbuhan dan perkembangan janin di dalam rahimnya dengan kata lain pada primigravida belum ada pengalaman melahirkan sehingga mampu beradaptasi dalam perubahanperubahan yang terjadi selama kehamilan mulai dari perubahan organ, hormon, dan lain-lain.

Hal ini sesuai dengan teori Prawirohardjo (2012), bahwa ibu primigravida belum mampu beradaptasi dengan hormon estrogen dan khorionik gonadotropin. Peningkatan hormon ini membuat kadar asam lambung meningkat, hingga muncullah keluhan rasa mual. Keluhan ini biasanya muncul di pagi hari saat perut ibu dalam keadaan kosong karena teerjadi peningkatan asam lambung, kadar gula dalam darah menurun sehingga pusing, lemas dan 
mual bisa terjadi. Janin memproduksi hormon khorionik gonadotropin yang merangsang indung telur untuk terus meningkat selama kehamilan sehingga berpengaruh terhadap melambatnya gerakan dan mengendurkan otot-otot pada sistem pencernaan, agar gizi makanan yang ibu konsumsi bisa lebih banyak di serap oleh bayi. Otot polos pada area rahim dan katup antara perut dan kerongkongan juga ikut mengendur, sehingga memicu meningkatnya asam lambung.

\section{Hubungan antara kehamilan ganda} dengan kejadian hiperemesis gravidarum pada ibu hamil

Berdasarkan tabel 2 didapatkan bahwa sebagian besar (64\%) responden dengan kehamilan ganda mengalami hiperemesis gravidarum, sedangkan sebagian kecil (22\%) responden dengan kehamilan tidak ganda tidak mengalamai hiperemesis gravidarum. Hasil uji statistik diperoleh nilai $p=0,024$ hal ini menunjukkan bahwa $p<0,05$ yang berarti ada hubungan antara kehamilan ganda dengan kejadian hiperemesis gravidarum.

Hal ini dikarenakan ibu hamil dengan Kehamilan ganda, kadar hormon estrogen dan HCG (Human Chorionic Gonadotropin) meningkat sehingga mual muntah pada kehamilan ini meningkat dibandingkan dengan kehamilan janin tunggal (Manuaba, 2010). Hasil penelitian ini sejalan dengan hasil penelitian yang dilakukan oleh Riska (2014) bahwa terdapat hubungan antara kehamilan ganda dengan kejadian hiperemesis gravidarum dengan nila $p$ value 0,010 .

\section{Hubungan antara molahidatidosa dengan kejadian hiperemesis gravidarum pada ibu hamil}

Berdasarkan tabel 3 didapatkan bahwa sebagian besar (75\%) responden dengan molahidatidosa mengalami hiperemesis gravidarum, sedangkan sebagian besar $(51,4 \%)$ responden dengan tidak mengalami molahidatidosa mengalami hiperemesis gravidarum. Hasil uji statistik diperoleh nilai $p=0,222$ hal ini menunjukkan bahwa $p>0,05$ yang berarti tidak ada hubungan antara molahidatidosa dengan kejadian hiperemesis gravidarum.

Hal ini disebabkan karena sebagian besar sampel adalah tidak mengalami molahidatidosa. Menurut Ben-Zion \& Taber MD (2013) bahwa ibu yang molahidatidosa yang tidak mengalami hiperemesis gravidarum karena faktor psikologis, keluarga yang harmonis, keluarga yang selalu memberikan support dan penderita yang menerima musibah yang menimpa dirinya.

Hal ini tidak sesuai dengan teori menurut Mansjoer (2017), yang mengatakan bahwa frekuensi terjadinya hiperemesis gravidarum yang tinggi pada mola hidatidosa dan gemelli menimbulkan dugaan bahwa faktor hormon memegang peranan, karena pada kedua keadaan 
tersebut hormon khorionik gonadotropin dibentuk berlebihan sehingga menyebabkan terjadinya hiperemesis gravidarum.

\section{Hubungan antara riwayat gastritis dengan} kejadian hiperemesis gravidarum pada ibu hamil

Berdasarkan tabel 4 didapatkan bahwa sebagian besar (53\%) responden dengan riwayat gastritis tidak mengalami hiperemesis gravidarum sedangkan sebagian besar (78\%) responden tidak dengan riwayat gastritis tidak mengalami hiperemesis gravidarum. Hasil uji statistik diperoleh nilai $p=0,358$ hal ini menunjukkan bahwa $p>0,05$ yang berarti tidak ada hubungan antara gastritis dengan kejadian hiperemesis gravidarum.

Hal ini tidak sesuai dengan teori menurut Hackley\&Barbara (2012) yang menyatakan bahwa wanita hamil dengan gastritis mungkin lebih rentan terhadap mual dan muntah. Muntah dan akan menghalangi ibu dan bayi untuk mendapatkan asupan nutrisi yang cukup. Jika ibu tidak mendapatkan asupan nutrisi yang cukup, maka akan berpengaruh pada janin. Misalnya kemungkinan janin mengalami BBLR.

\section{KESIMPULAN}

Setelah melakukan penelitian terhadap 45 responden, maka dapat disimpulkan terdapat hubungan gravida dengan hiperemesis gravidarum di RB Zakat
Surabaya, terdapat hubungan kehamilan ganda dengan hiperemesis gravidarum di RB Zakat Surabaya, tidak terdapat hubungan mola hidatidosa dengan hiperemesis gravidarum di RB Zakat Surabaya dan tidak terdapat hubungan riwayat penyakit gastritis dengan hiperemesis gravidarum di RB Zakat Surabaya.

\section{DAFTAR PUSTAKA}

Ben-Zion dan Taber MD. 2013. Kedaruratan Obstetri dan Ginekologi. Jakarta:EGC

Depkes RI \& Usaid, 2013. Program Perencanaan Persalinan dan Komplikasi dan Pencegahan Komplikasi (P4K) dalam rangka mempercepat penurunan $A K I \& A K B$, Jakarta.

Hackley \& Barbara,2012. Primary Care of Women A Guide forMidwives Providers 1 edition: Jones \& Bartlett Learning

Manuaba, IBG, 2010. IImu Kebidanan, penyakit Kandungan Edisi ketiga. Jakarta: Media Aesculapius

Mansjoer, Arif. 2017. Kapita Selekta Kedokteran. Jakarta: Media Aesculapius.

Prawirohardjo S, 2012. Ilmu Kebidanan. Jakarta: PT. Bina Pustaka Sarwono.

Price \& Wilson, 2015. Konsep Klinis ProsesProses Penyakit Edisi 6 Vol. 2. Jakarta: ECG.

Purniantika. 2011. Komplikasi dan Penyulit dalam kehamilan. Jakarta: ECG.

Riska. 2014. Faktor-Faktor Yang Mempengaruhi Kejadian Hiperemesis Gravidarum di Puskesmas Tegal.

Rocmawati. 2011. Faktor-faktor yang berhubungan dengan kejadian hiperemesis gravidarum pada ibu hamil trimester I di Puskesmas Mattirobulu, Kabupaten Pinrang.

Survey Demografi dan Kesehatan Indonesia, 2014. Laporan Pendahuluan SDKI 2014. 
Tiran \& Denise, 2013. Mual \& Muntah Kehamilan. Jakarta: ECG.

WHO, 2015. Reduction of maternal mortality. A Joint WHO/ UNFPA/ UNICEF/ world bank statement, Geneva. 